\title{
Isolation and Identification of Probiotics Pediococcus pentosaceus2 and Pediococcus pentosaceus1 from the Gut of Tilapia Guineensis for Use in Aquaculture Production
}

\author{
C. I. Ayo-Olalusi \\ Nigerian Institute for Oceanography and Marine Research, P. M. B. 12729, Lagos, Nigeria \\ Ireti.ayoolalusi@yahoo.com
}

\begin{abstract}
Aquaculture industry is the fastest-growing food producing sector but fish diseases has been a major threat to the growth. Bacterial infections are one of the causes of mortality in fish and the use of antibiotics has resulted in resistant strain of bacteria in fish. Therefore role of probiotics is being considered as alternative. Studies were carried out to isolate and identify probiotics from the gut of Tilapia guineensis. Guts removed from dissected fish were suspended in $9 \mathrm{ml}$ of saline diluents homogenized and allowed to pour in MRS broth and agar medium. The isolated lactobacillus was re dissolved and shaken homogenously incubated at $37^{\circ} \mathrm{C}$ aenarobically for 24 hrs. The culture obtained were subculture on MRS at pH 6.2 for discrete colonies. Single colony of lactobacillus was isolated using colony morphology and some biochemical tests. The isolated bacteria were identified using biochemical test and API CH in conjunction with API CHL medium for the identification of probiotics. Bacteria isolated from the gut of Tilapia guineensis were identified as pediococcus pentosaceus2 and pediococcus pentosaceusl by observing their colony morphology, physiological and as well as some biochemical characteristics. Microscopically they were Gram-positive, rod shaped, non- motile, catalase negative and absence of Endospore.
\end{abstract}

Keywords: pediococcus pentosaceus2, pediococcus pentosaceus1, probiotics and Tilapia guineensis.

\section{INTRODUCTION}

Fish diseases are major problem for the fish farming Industry and among those bacterial infections are considered to be a major cause of mortality in fish [1].

However, the excessive and inappropriate use of antibiotics has resulted in the presence of resistant strains of bacteria in fish culture [2].

In addition, there are environmental problems associated with the antibiotics [3]. Therefore, the need for alternatives is increasing and the contribution of probiotics may be considerable. With increasing demand for environment friendly aquaculture, the use of probiotics in aquaculture is now widely accepted [4-7]. Probiotics are harmless bacteria that help in the well being of the host animal and contribute, directly or indirectly to protect the host animal against harmful bacterial pathogens. Probiotics are lactic acid bacteria (LAB) characterized as Gram- positive, non-motile, non-spore forming bacteria, non-pigmented [8], and catalyst negative.

The most commonly used organisms in probiotic preparations are lactic acid producing bacteria such as lactobacilli, streptococci, Bifidobacteria, Bacillus spp. and fungi like Sacharomyces cerevisiae, Sacharomyces boulardii and Aspergillus oryzae [9, 10]. However, lactic acid bacteria (LAB) have attained major attention for probiotic activity and have generally been considered as good probiotic organisms $[11,12]$.

The aim of the study was to isolate and identify resident probiotics from the gut of Tilapia guineensis and classify them based on their morphological and biochemical characteristics.

\section{MATerials AND Methods}

\subsection{Collection of Samples and Laboratory Procedure}

Freshly caught fish of Tilapia guineensis were procured from fish landing site at Makoko, packed in iceboxes and transferred to the Nigerian Institute for Medical Research laboratory within $1 \mathrm{hr}$. The skin was then washed with $70 \%$ ethanol before opening the ventral surface with sterile scissors. The 


\section{I. Ayo-Olalusi}

fish were dissected to remove the gut and divided into foregut, midgut and hind gut in other to determine where there is more concentration of probiotics in these regions. $1 \mathrm{~g}$ of intestine was taken from each fish sample and suspended in $9 \mathrm{ml}$ of sterile saline diluents $(0.85 \% \mathrm{NaCI})$. The gut samples were homogenized in a blender using saline, serially diluted and allowed to grow in MRS broth medium.

\subsection{Preparation of Media}

The bacteria Lactobacillus spp. was isolated from fish gut by using modified MRS broth and MRS agar media. 52grams of the media was suspended in one litter of distilled water each. They were mixed well, heated agitating frequently until complete dissolution of the medium. Each medium was dispensed in adequate containers and sterilized in autoclave at $121^{\circ} \mathrm{C}$ for 12 minutes. Additionally, $0.05 \%$ cysteine was added to MRS to improve the specificity of this medium for isolation of lactobacillus. The $\mathrm{pH}$ of the media was adjusted to 6.2.

\subsection{Isolation of Probiotics}

Lactobacillus was isolated from fish gut using MRS medium. $1 \mathrm{ml}$ of each sample was dissolved in 9 $\mathrm{ml}$ of MRS broth at $\mathrm{pH}$ 6.2. After dissolving into MRS broth they were shaken homogeneously and incubated at $37^{\circ} \mathrm{C}$ anaerobically for $24 \mathrm{hrs}$. The cultures were subjected to five subculture at $37^{\circ} \mathrm{C}$ under low $\mathrm{pH}(\mathrm{pH}$ 6.2) and anaerobic condition in the presence of $10 \% \mathrm{CO}$ to remove unwanted bacteria. After $24 \mathrm{hrs}$ the broth was sub-cultured on MRS for discrete colonies, agar media at pH 6.2. Finally, the single colony of lactobacillus was isolated by observing their colony morphology and some biochemical tests (Gram staining, catalase, endospore and motility test) and the culture were maintained in MRS broth at $\mathrm{pH}$ 5.5. The isolates were prepared using a McFarland standard of 1.0 $\mathrm{X} 10^{8}$ by adding sterile distilled water

\subsection{Some Biochemical Test for LAB}

\subsection{Grams Staining}

Heat fixed bacterial smear slide was placed on a staining rack stained with crystal violet for 1 minute, washed in tap water, cover with grams iodine for 1 minute, re-washed, decolourised by washing the slide briefly in acetone (2-3 seconds) 1 and counterstained for 10 minutes in Safranin. The smears were washed thoroughly with water and gentle air dried and observed under oil immersion.

\subsection{Catalyst Test}

A loopful of the culture was placed on a slide and few drops of $10 \%$ hydrogen peroxide were added. The slides were observed for effervescence.

\subsection{Identification}

The isolated bacteria were identified as Lactobacillus spp. by observing their morphological characteristics and by mean Gram staining, motility test, catalase test, $0.4 \%$ bacteriostactic phenol tolerance test and $1-10 \% \mathrm{NaCl}$ tolerance test. The identity of the cultures was based on the characteristics of the lactobacilli as described in Bergey's Manual of Determinative Bacteriology (Azcarate-Peril), fermentation of different carbon sources (API $50 \mathrm{CHL}$, BioMérieux). This is a ready- to- use medium which enables the fermentation of 49 carbohydrates on the API $50 \mathrm{CH}$ strip to be studied. A suspension is made in the medium with the microorganism to be tested and each tube of the strips inoculated. Carbohydrates were fermented to acids during incubation which produced a decrease in $\mathrm{pH}$. This was detected by the color change of the indicator. API analysis was used for determination of the biochemical profile of the strain and its identification.

\section{RESULTS AND DISCUSSION}

Bacteria isolated from the foregut, midgut and hindgut of Tilapia guineensis were identified as pediococcus pentosaceus 2 and pediococcus pentosaceus 1 by observing their colony morphology, physiological and as well as some biochemical characteristics (Table 1). Microscopically they were Gram-positive, rod shaped, non- motile, catalase negative and absence of Endospore Plate 1 and 2. Plate 3 represented the API $50 \mathrm{CH}$ strip consists of wells, each one of them was rehydrated with bacterial suspension and the strips were incubated for identification of bacteria. Pediococcus 
pentosaceus being a gram positive bacterium, non-motile with no endospore, strives anaerobically and forms a member of the industrially important lactic acid bacteria (LAB) that grows on lactobacilli MRS broth at $37^{\circ} \mathrm{C}$. Summary of the result of isolation and identification of probiotics from Tilapia guineensis gut (foregut, midgut and hindgut) is represented in Table 2.The result obtained indicated a high accuracy of T. guineesis probiotics. Pediococcus pentosaceus produces antimicrobial activities against many gram positive bacteria species, including the food borne pathogen Listeria monocytogenes. Ferguson et al. [13] reported that dietary supplementation of Pediococcus acidilactici increases the intestinal microbial load of red tilapia, Oreochromis niloticus. Merrifield et al. [14] also reported that Pediococcus acidilactici has a significant effect on intestinal microflora of rainbow trout, Oncorhynchus mykiss. Moslehi et al., [15] stated that Pediococcus pentosaceus had positive effect on the body composition and intestinal microflora of Siberian sturgeon, Acepenser baerri. The author reported that Pediococcus pentosaceus has a proper colonization in the gut of treated fish species. Corr et al., [16] reported that bacteriocin producing LAB can effectively suppressed the growth of listeria in mice and to eradicate its presence. Colony forming unit $\left(\mathrm{CFUml}{ }^{-1}\right)$ isolated from the gut of Tilapia guineensis on MRS agars media is represented in Table 3. Identification and characterization of these probiotics are required in order to develop probiotic bacteria with divers' antimicrobial potentials. The probiotics may have potential use as an additive in the food industry particularly processed food in which some bacillus species are potential spoilage. Further study would be the incorporation of these probiotics into fish feed and evaluate their performance in terms of growth, nutrient utilization and lessen the diseased burden on some culturable fish species which could be of economic important in aquaculture production.

Table 1. Colony morphology, physiological and biochemical characteristics of the isolated bacteria strain of pediococcus pentosaceus 2 and pediococcus pentosaceus 1

\begin{tabular}{|l|l|l|l|}
\hline Colony morphology/physiological features & Biochemical tests \\
\hline Characteristics & Descriptions & Characteristics & Descriptions \\
\hline Cell shape & Rod & Catalase & negative (+) \\
Pigment & White- creamy & $0.4 \%$ phenol tolerance test & Positive (+) \\
Gram staining & Positive & $5 \%$ Nacl tolerance test & Positive (+) \\
spores & No endospores & Temperature & 25-40 degree C \\
motility & Non-motile & Period of incubation & 24-48hrs \\
Texture & Dry & Atmosphere & Anaerobic \\
Colony appearance & Smooth & Optimum pH & $4.5-7.0$ \\
\hline
\end{tabular}

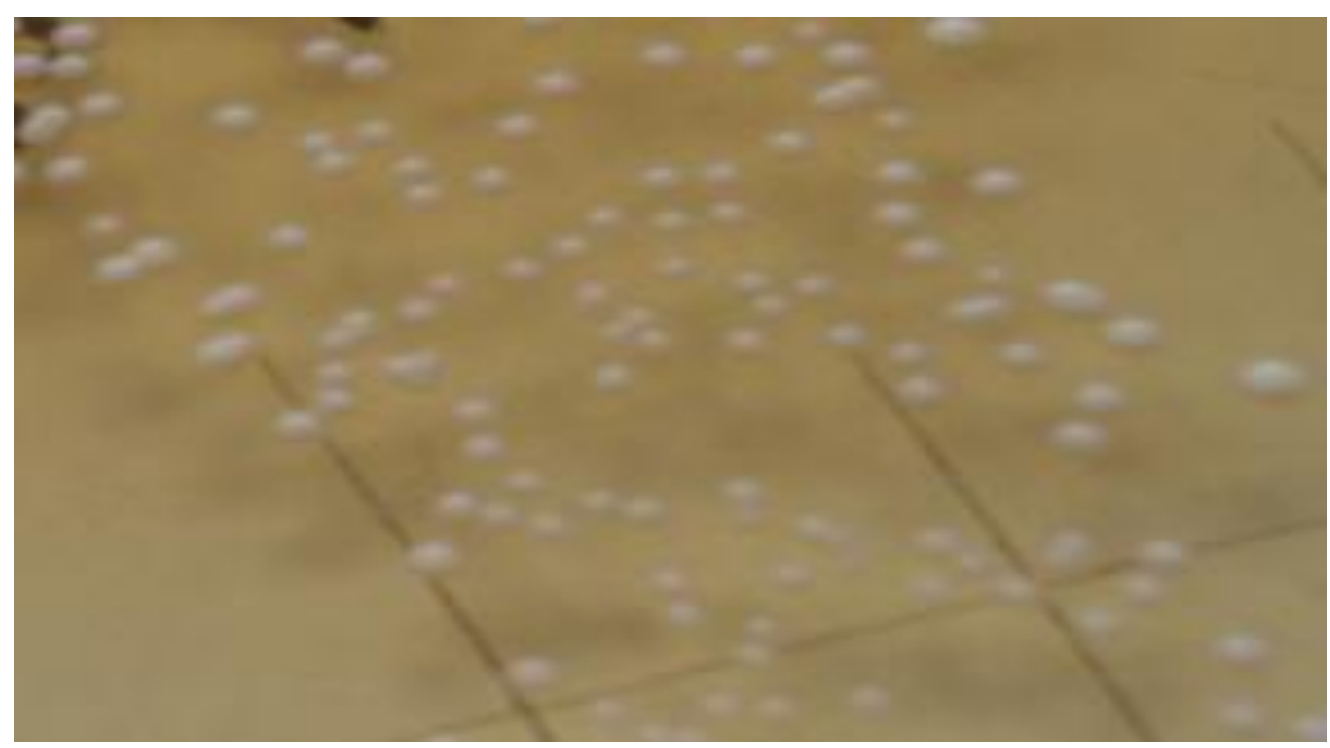

Plate 1. Colonies of pediococcus pentosaceus 2 and pediococcus pentosaceus 1

Table 3. Summary of the result of isolation and identification of probiotics from Tilapia guineensis gut (foregut, midgut and hindgut)

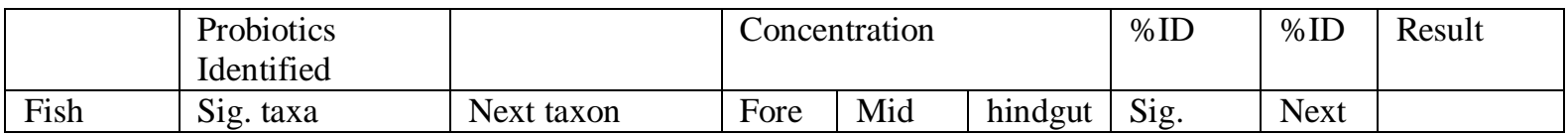




\section{I. Ayo-Olalusi}

\begin{tabular}{|l|l|l|l|l|l|l|l|l|}
\hline \hline Specimen & & gut & gut & & taxa & taxa & \\
\hline 1 & $\begin{array}{l}\text { Pediococcus } \\
\text { pentosaceus 2 }\end{array}$ & $\begin{array}{l}\text { Pediococcus } \\
\text { pentosaceus } 1\end{array}$ & ++ & +++ & +++ & 99.9 & 0.1 & $\begin{array}{l}\text { Excellent } \\
\text { ID }\end{array}$ \\
\hline 2 & $\begin{array}{l}\text { Pediococcus } \\
\text { pentosaceus 2 }\end{array}$ & $\begin{array}{l}\text { Pediococcus } \\
\text { pentosaceus } 1\end{array}$ & +++ & +++ & +++ & 99.6 & 0.4 & $\begin{array}{l}\text { Excellent } \\
\text { ID }\end{array}$ \\
\hline 3 & $\begin{array}{l}\text { Pediococcus } \\
\text { pentosaceus 2 }\end{array}$ & $\begin{array}{l}\text { Pediococcus } \\
\text { pentosaceus } 1\end{array}$ & ++ & +++ & +++ & 99.6 & 0.4 & $\begin{array}{l}\text { Excellent } \\
\text { ID }\end{array}$ \\
\hline 4 & $\begin{array}{l}\text { Pediococcus } \\
\text { pentosaceus 2 }\end{array}$ & $\begin{array}{l}\text { Pediococcus } \\
\text { pentosaceus } 1\end{array}$ & +++ & +++ & +++ & 99.1 & 0.9 & $\begin{array}{l}\text { Excellent } \\
\text { ID }\end{array}$ \\
\hline 5 & $\begin{array}{l}\text { Pediococcus } \\
\text { pentosaceus 2 }\end{array}$ & $\begin{array}{l}\text { Pediococcus } \\
\text { pentosaceus } 1\end{array}$ & ++ & +++ & +++ & 99.4 & 0.6 & $\begin{array}{l}\text { Excellent } \\
\text { ID }\end{array}$ \\
\hline 6 & $\begin{array}{l}\text { Pediococcus } \\
\text { pentosaceus 2 }\end{array}$ & $\begin{array}{l}\text { Pediococcus } \\
\text { pentosaceus } 1\end{array}$ & ++ & +++ & +++ & 99.8 & 0.2 & $\begin{array}{l}\text { Excellent } \\
\text { ID }\end{array}$ \\
\hline
\end{tabular}

Keys:

ID - Identification

XX- Less abundance

XXX - More abundance.

Sig.- significance

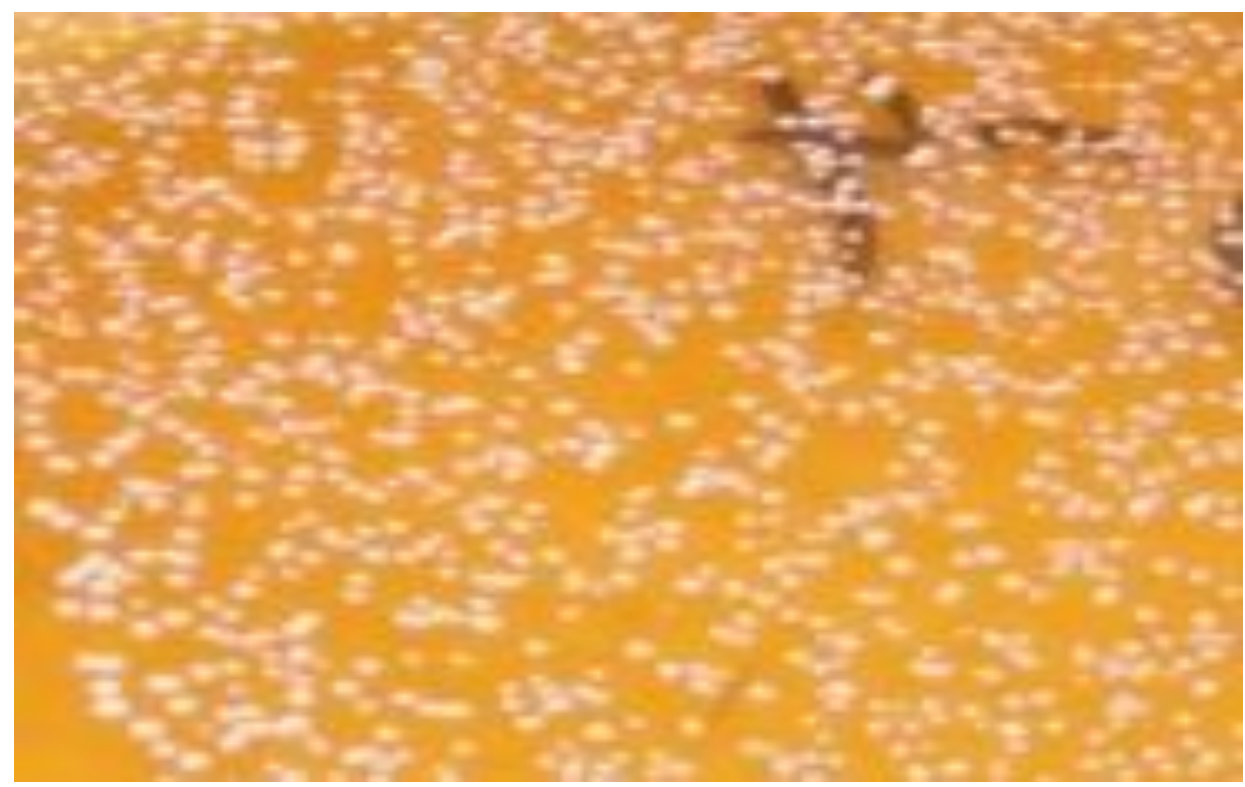

Plate 2. Colonies of pediococcus pentosaceus 2 and pediococcus pentosaceus 1

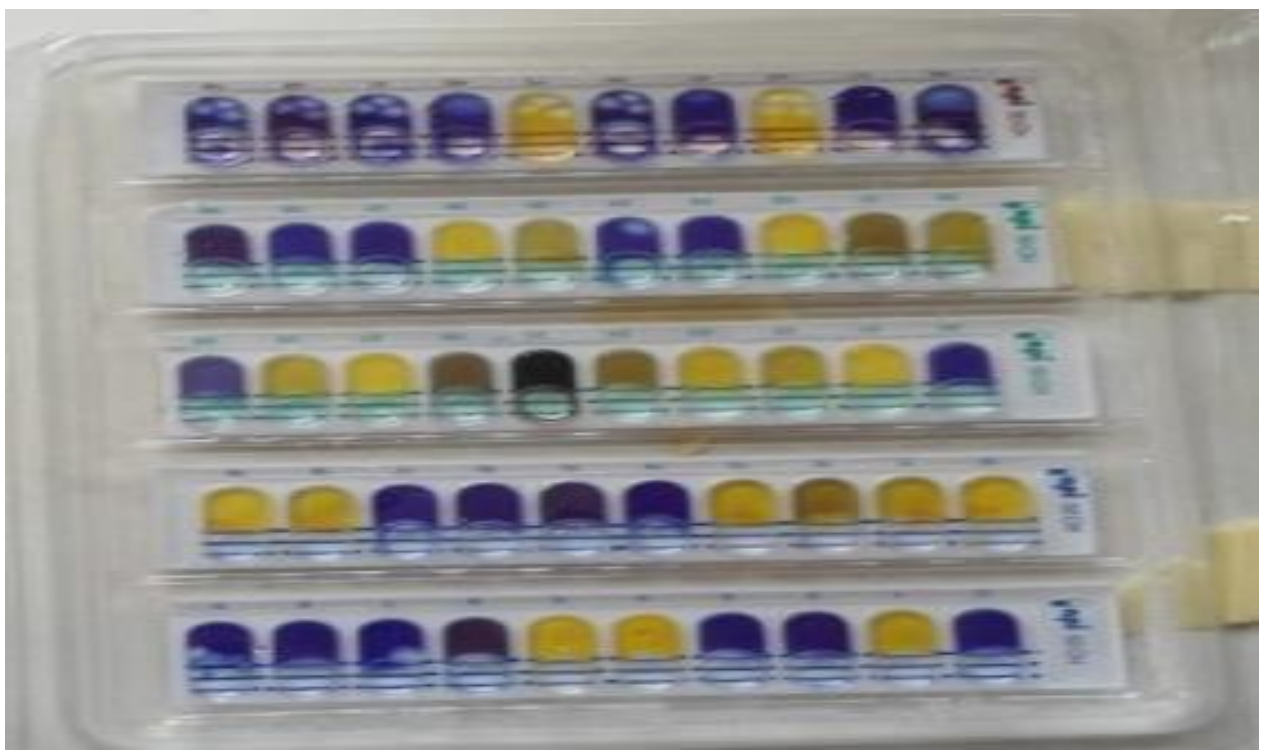

Plate 3. API kits for Identification of Probiotics. 
Isolation and Identification of Probiotics Pediococcus pentosaceus2 and Pediococcus pentosaceus1 from the Gut of Tilapia Guineensis for Use in Aquaculture Production

Table 3. Colony forming unit $\left(\mathrm{CFUml}^{-1}\right)$ isolated from the gut of Tilapia guineensis on MRS agars media.

\begin{tabular}{|l|l|l|l|l|l|}
\hline $\begin{array}{l}\text { Fish } \\
\text { specimens }\end{array}$ & Weight of fish $(\mathrm{g})$ & $\begin{array}{l}\text { Total length } \\
(\mathrm{cm})\end{array}$ & $\begin{array}{l}\text { Standard length } \\
(\mathrm{cm})\end{array}$ & No of plates & CFUml-1 \\
\hline 1 & 37.06 & 11.0 & 8.6 & 5 & $3.20 \times 10^{8}$ \\
2 & 43.40 & 12.8 & 8.8 & 5 & $2.89 \times 10^{8}$ \\
3 & 15.50 & 8.2 & 6.5 & 5 & $3.10 \times 10^{8}$ \\
4 & 86.50 & 17.1 & 15.0 & 5 & $3.02 \times 10^{8}$ \\
5 & 15.00 & 8.9 & 6.9 & 5 & $3.20 \times 10^{8}$ \\
\hline
\end{tabular}

\section{ACKNOWLEDGEMENT}

I would like to express our sincere gratitude and profound appreciation to the staff of Department of microbiology of Nigerian Institute of Medical Research for their contribution and the use of their laboratory to carry out the research.

\section{REFERENCES}

[1] Gomez-Gil, B., Roque, A., Turnbull, J.F. 2000. The use and selection of probiotic bacteria for use in the culture of larval aquatic organisms. Aquaculture, Vol.191, No.1-3, pp. 259-270.

[2] Nomoto, K. 2005. Prevention of infections by probiotics. Journal of Bioscience and Bioengineering, Vol. 100. No.6, pp.583-592.

[3] Wang, Y.B. and Xu, Z.R. 2004. Probiotics treatment as method of biocontrol in aquaculture. Feed Research. No.12, pp. $42-45$ (in Chinese).

[4] Wang, Y.B., Xu, Z.R. and Xia, M.S., 2005. The effectiveness of commercial probiotics in Northern White Shrimp (Penaeus vannamei L.) ponds. Fisheries Science, Vol. 71. No.5, pp. 1036-1041.

[5] Vine, N.G., W.D. Leukes and H. Kaiser. 2006. Probiotics in marine larviculture. FEMS Microbiol. Rev., 30: 404-427.

[6] Wang, Y.B. and Xu, Z.R. (2006). Effect of probiotics for common carp (Cyprinus carpio) based on growth performance and digestive enzyme activities. Animal Feed Science and Technology, Vol. 127. No.3-4, pp. 283-292.

[7] Kesarcodi-Watson, A., Kaspar, H., Lategan, M.J., Gibson, L. (2008). Probiotics in aquaculture: The need, principles and mechanisms of action and screening processes. Aquaculture, Vol. 274. No.1, pp.1-14.

[8] Verschuere, L., Rombaut, G., Sorgeloos, P., Verstraete, W., 2000. Probiotic bacteria as biological agents in aquaculture. Microbiology and Molecular Biology Reviews, Vol. 64. No.4, pp.655-671.

[9] Hassan, A.N. and J.F. Frank. 2001. Starter cultures and their use, pp.151-206. In, E.H. Marth and J.L. Steele (eds). Applied Dairy Microbiology, 2nd edition. Marcel Dekker, Inc, New York.

[10] Fuller, R.1992. Probiotics: The scientific basis. Chapman \& Hall, London, pp: 398.

[11] Medina, R., M. Katz, S. Gonzalez and G. Oliver. (2001). Characterization of the lactic acid bacteria in ewe's milk and cheese from Northwest Argentina. J. Food Prot., 64(4): 559-563.

[12] Saavedra, J. M. 2001. Clinical applications of probiotic agents. Amer. J. Clin. Nutr., 73: 1147S$1151 \mathrm{~S}$.

[13] Sullivan, M. G. O., G. Thornton, G. C. O. Sullivan and J. K. Collins 1992. Probiotic bacteria: myth or reality? Trends Food Sci. Technol., 3: 309-314.

[14] Ferguson R.M.W., Merrifield D.L., Harper G.M., Rawling M.D., Mustafai IS., Picchnietti S., Balcazar J.L., Davies S.J. 2010. The effect of Pediococcus acidilactici on the gut microbiota and immune status of on-growing red tilapia (Oreochromis niloticus). Journal of Applied microbiology 109(3): 51-62.

[15] Merrifield D.L., Bradley G., Harper G.M., Baker R.T.M., Munn C.B., Davies S.J. 2011. Assesment of the effect of vegetative and lyophilized Pediococcus acidlactici on growth, feed utilization, intestinal colonization and health parameters of rainbow trout (Oncorhnchus mykiss Walbaum). Aquaculture Nutrition, 17: 73-79. 


\section{I. Ayo-Olalusi}

[16] Moslehi F., Masoud S., Masouleh A.S. 2016. Effects of Pediococcus pentosaceus as a probiotic on intestinal microbiota and body composition of Siberian sturgeon, Acipenser baerii. Int. J. Aquat.Biol. 4 (1): 11-16.

[17] Corr, S. C., Li, Y., Riedel, C. U., O'Toole, P. W., Hill, C. \& Gahan, C. G. 2007. Bacteriocin production as a mechanism for the anti-infective activity of Lactobacillus salivarius UCC118. Proc Natl Acad Sci U. S. A 104, 7617-7621. 